Gut, 1962, 3, 146

\title{
Subcutaneous fat necrosis, 'polyarthritis', and pancreatic disease
}

\author{
P. F. LUCAS AND T. K. OWEN \\ From the Royal Victoria Hospital, Bournemouth
}

EDITORIAL SYNOPSIS A case report is presented with a discussion on the association of subcutaneous fat necrosis and pancreatic disease.

Widespread panniculitis has already been described in association with acute pancreatitis (Chiari, 1883; Hansemann, 1889; Jenckel, 1914; Zaaijer, 1935; Scarselli, 1954; Kushner and Szanto, 1958; Cohen, 1959; Swerdlow, Berman, Gibbel, and Valaitis, 1960), with subacute pancreatitis (Blauvelt, 1946; Mayoral, Gompertz, and Young, 1959), and with carcinoma of pancreas (Berner, 1908; Hegler and Wohlwill, 1930; Titone, 1936; Auger, 1947; Osborne, 1950; Belsky and Cornell, 1955; Szymanski, 1959; Bluefarb, 1959). The object of this paper is to describe a case in association with pancreatic calculi, not previously described to our knowledge, and to examine the mechanism of this syndrome and its relationship to the Weber-Christian syndrome of relapsing panniculitis.

\section{CASE HISTORY}

The patient was a clerk, aged 46 , who was admitted to the Royal Victoria Hospital on 9 May 1960. Three weeks previously his left ankle became swollen, red, and painful while at work. Next day the metacarpophalangeal joints of the hands, including the thumbs, became similarly affected. Within one week, both knees, ankles, wrists, and all joints of the right hand and of the toes of both feet were affected. One week previously, the metacarpophalangeal joint of the right thumb discharged watery fluid. Cortisone was given to the patient at home but was stopped after four days because of the appearance of red lumps on the legs. Penicillin was given without effect. The pain and swelling of the joints became progressively more severe, and he became generally ill without other specific symptoms. He had lost half a stone in weight.

He had had bacillary dysentery and malaria in the past and had been boarded out of the Services on account of psychoneurosis. Three years before this illness, he had been seen by a physician because of bouts of vomiting over three years; a cholecystogram was normal and the symptoms were thought to be psychogenic. Vomiting continued to trouble him about one day in each month but did not progress. Three weeks before this admission he had vomited and passed bright blood per rectum; examination showed haemorrhoids. His family health record was good. He was a heavy smoker (40 to 50 cigarettes daily) and regularly drank three pints of beer and four tots of spirits daily.

On admission, he was obviously ill and in pain (temperature 102 to $103^{\circ} \mathrm{F}$., and pulse 90 to 120 per minute). The joints were inflamed, each being bright red, swollen, hot and tender, affecting both first and second metacarpophalangeal joints, wrists, ankles, and most of the toes at their bases. Both knees were less severely affected and there was tenderness over the lumbar spine and buttocks. The heart and lungs were normal, blood pressure $155 / 95 \mathrm{~mm}$. Hg. The abdomen was normal. There were five localized, red, painless nodules on the shins, suggestive of erythema nodosum.

Initial investigations showed: $\mathrm{Hb} 64 \%(9 \cdot 3 \mathrm{~g}$. per $100 \mathrm{ml}$.), W.B.C. 15,200 per c.mm. (77\% polymorphs), E.S.R. $65 \mathrm{~mm}$. in one hour. The blood uric acid level was $3.3 \mathrm{mg}$. per $100 \mathrm{ml}$. Blood cultures were sterile. A chest radiograph showed a 'fullness' of the left upper hilum; radiographs of the hands showed sharply defined punched-out areas of bone destruction in the phalanges and lower end of the radius and ulna, with similar changes in the feet. The ankles showed some osteoporosis, the pelvis was normal, and the spine showed possible wedging of D.12.

He was seen in consultation with Mr. N. Ross Smith and was initially thought to have a septicaemia with suppurative arthritis; the possibility of bronchial carcinoma and myelomatosis was considered. Bronchoscopy was normal, but a bronchogram showed some distortion of the left upper lobe stem bronchus with limited filling. No Bence-Jones protein was found in the urine and electrophoresis showed only some reduction in albumin and a slight increase in alpha 2 globulin.

Viscid fluid, $30 \mathrm{ml}$., was aspirated from the left knee. 'Thick, adherent pus' was drained from the left thumb. A few days later the right heel discharged spontaneously. The right wrist and both ankles were then laid open, packed, and plastered; 'caseous material' was drained 
and bone biopsies were taken. The material drained seemed to lie in the subcutaneous tissues rather than in the joints. No more than a few necrotic pus cells were seen in any of these specimens. There were no organisms and no acid-fast bacilli, and cultures, aerobic, anaerobic, and on Sabouraud's medium were sterile. Section of the material discharged from the heel showed necrotic fat, and biopsy of a subcutaneous nodule also showed fat necrosis with some fine granular deposits of calcium.

During this time there was no great change in the patient's condition. His temperature was irregular and was unaffected by large doses and various combinations of antibiotics. The serum amylase was unrecordable (reported as above 16,000 Somogyi units/100 ml.). Serum calcium was $8.6 \mathrm{mg} . / 100 \mathrm{ml}$., and serum phosphate $3.6 \mathrm{mg} . / 100 \mathrm{ml}$. Liver function tests were normal; the serum cholesterol level was $110 \mathrm{mg} . / 100 \mathrm{ml}$; the urinary amino-acids were normal. Haemoglobin fell to $51 \%$ ( $7 \cdot 4$ g. per $100 \mathrm{ml}$.) and W.B.C.s reached 24,000 per c.mm. (90\% polymorphs, $6 \%$ eosinophils). The Wassermann reaction and the G.C.F.T. were negative. The serum amylase fell to 8,500 units a few days before death. The possibility of laparotomy was discussed but it was felt that the patient's general condition would not stand it. He deteriorated steadily, rapidly losing flesh. Numerous red nodules appeared in the skin, especially over the pressure points, some of which broke down and discharged necrotic material. Prednisone, $60 \mathrm{mg}$. daily, was ineffective in the last week of his illness. He died on 4 June, one month after admission and seven weeks after his initial symptoms.

At necropsy, the chief feature was the finding of calculi in the pancreatic ducts. The largest was $7 \times 7 \times 5 \mathrm{~mm}$. near the ampulla of Vater but many of the smaller ducts contained calcareous debris. The ducts behind the obstruction were dilated and contained gelatinous material. There was some associated, but not very severe, inflammatory infiltration of the pancreas. There were a few small areas of fat necrosis adjacent to the pancreas. The stomach showed a small shallow ulcer near the pylorus, but there were no other significant findings.

A section of the ulna showed areas of necrosis of the marrow and of the bony trabeculae. A section of a wrist joint showed no histological changes.

\section{DISCUSSION}

The serum amylase level was raised whenever recorded in all the cases in which disease of the pancreas has been described in association with panniculitis, and it seems probable that true digestion of tissue occurs. Values of over 600 units have usually been found and have waxed and waned with the relapse and remission of the panniculitis in those cases associated with pancreatitis. Those cases associated with neoplasm have all progressed to death without remission. Descriptions of these cases scattered in the literature are strikingly similar. Some had abdominal symptoms of tumour, others presented no clue to the underlying disease, the diagnosis being made at necropsy, especially in the neoplastic cases. The common features are subcutaneous panniculitis or fat necrosis, especially in the region of joints and over pressure points, so that many cases are described as arthritic, sometimes relapsing, but persistent in the neoplastic cases, with a high E.S.R. and a high amylase level; many of the patients had leucocytosis, occasionally eosinophilia, and often progressive anaemia and loss of flesh. This clinical syndrome strongly suggests pancreatic disease.

In several cases of carcinoma of the pancreas the pancreatic duct was blocked by growth but in others the lesion was in the tail. Popper and Necheles (1940) have demonstrated in animals that obstruction of the pancreatic duct leads to an excess of amylase and lipase in the portal vein and thoracic duct. Auger (1947) noted that all the growths were adenocarcinomata and suggested that they may be functioning tumours secreting ferments, a suggestion supported by Sugiura, Pack, and Stewart (1936), who found a great excess of amylase and protease but not of lipase in such a tumour. Such an explanation cannot apply to pancreatitis and an obstructive lesion seems a more likely explanation, although it seems peculiar that more cases do not show these features. This line of thought was followed by Opie as long ago as 1910. The case of panniculitis described by De Lor and Martz (1955) and that of Hegler and Wohlwill (1930) are the only ones in which necrotic lesions have been reported in the radiographs of bone. No diagnosis had been made in the former case at the time of the report but it seems likely that the patient had a pancreatic lesion.

The skin lesions of the Weber-Christian syndrome (Weber, 1925; Christian, 1928) are identical both clinically and histologically to those in these cases. This is usually a mild disease although attention has been drawn to visceral involvement (Oram and Cochrane, 1958), to joint lesions (e.g., Goldberg and Ritzmann, 1958), and to the widespread panniculitis found at necropsy in various parts of the body. No pancreatic disease has been found in the eight necropsies recorded in this syndrome (Steinberg, 1953); most of the deaths resulted from associated disease or intercurrent infection. We have been unable to find any cases in which the serum amylase has been recorded, and it seems clear that such investigations should be carried out, as no cause for this syndrome has ever been demonstrated and, with the doubtful exception of steroids, no effective treatment is known.

We wish to express our thanks to Dr. T. R. Riley for the radiological reports and to Dr. D. Stern for the biochemical investigations. 


\section{REFERENCES}

Auger, C. (1947). Acinous cell carcinoma of the pancreas with extensive fat necrosis. Arch. Path. (Chicago), 43, 400-405.

Belsky, H., and Cornell, N. W. (1955). Disseminated focal fat necrosis following radical pancreatico-duodenectomy for acinous carcinoma of head of pancreas. Ann. Surg., 141, 556-562.

Berner, O. (1908). Subkutane Fettgewebsnekrose. Virchows Arch. path. Anat., 193, 510-518.

Blauvelt, H. (1946). A case of acute pancreatitis with subcutaneous fat necrosis. Brit. J. Surg., 34, 207-208.

Bluefarb, S. M. (1959). Subcutaneous fat necrosis and polyarthritis in a patient with pancreatitis (Discussion). A.M.A. Arch. Derm. Syph., 80, 602.

Chiari, H. (1883). Ueber die sogenannte Fettnekrose. Prag. med. Wschr., 8, 285 and 299.

Christian, H. A. (1928). Relapsing febrile nodular nonsuppurative panniculitis. Arch. intern. Med., 42, 338-351.

Cohen, D. (1959). Subcutaneous fat necrosis and polyarthritis in a patient with pancreatitis. A.M.A. Arch. Derm. Syph., 80, 602-603.

De Lor, C. J., and Martz, R. W. (1955). Weber-Christian disease with bone involvement. Ann. intern. Med., 43, 591-598.

Goldberg, L. M., and Ritzmann, L. W. (1958). Unusual manifestations in a case of relapsing, nodular, febrile panniculitis (WeberChristian disease). Amer. J. Med., 25, 788-795.

Hansemann, D. (1889). In Discussion following paper by Langerhans entitled Demonstration eines Präparats von Pankreasnekrose. Berl. klin. Wschr., 26, 1115.

Hegler, C., and Wohlwill, F. (1930). Fettgewebsnekrosen in Subcutis und Knochenmark durch Metastasen eines Carcinoms des Pankreasschwanzes. Virchows Arch. path. Anat., 274, 784-802.

Jenckel (1914). Zur Pathologie und Therapie der akuten Pankreasnekrose. Dtsch Z. Chir., 131, 253-310.

Kushner, D. S., and Szanto, P. B. (1958). Fulminant polyarthritis, fever and cutaneous nodules in an alcoholic patient. J. Amer. med. Ass., 167, 1625-1632.
Mayoral, J. W., Gompertz, M. L., and Young, J. M. (1959). Subcutaneous fat necrosis associated with pancreatitis and portal cirrhosis. Gastroenterology, 36, 884-887.

Opie, E. L. (1910). Disease of the Pancreas, 2nd ed., p. 190. Lippincott, Philadelphia.

Oram, S., and Cochrane, G. M. (1958). Weber-Christian disease with visceral involvement. Brit. med. J., 2, 281-284.

Osborne, R. R. (1950). Functioning acinous cell carcinoma of the pancreas accompanied with widespread focal fat necrosis. Arch. intern. Med., 85, 933-943.

Popper, H. L., and Necheles, H. (1940). Pathways of enzymes into the blood in acute damage of the pancreas. Proc. Soc. exp. Biol. (N.Y.), 43, 220-222.

Scarselli, E. (1954). Pancreatite acuta emorragica con lesioni necrotiche ed emorragiche della cute e del sottocutaneo. G. Clin. med., 35, 1232-1261.

Steinberg, B. (1953). Systemic nodular panniculitis. Amer. J. Path., 29, 1059-1081.

Sugiura, K., Pack, G. T., and Stewart, F. W. (1936). A study of the enzyme content of a parenchymatous adenocarcinoma of pancreas and a comparison with the normal human pancreas. Amer. J. Cancer, 26, 351-357.

Swerdlow, A. B., Berman, M. E., Gibbel, M. I., and Valaitis, J. (1960). Subcutaneous fat necrosis associated with acute pancreatitis. J. Amer. med. Ass., 173, 765-769.

Szymanski, . (1959). Subcutaneous fat necrosis and polyarthritis in a patient with pancreatitis (Discussion). A.M.A. Arch. Derm. Syph., 80, 602.

Titone, M. (1936). Ubber ungewöhnlich ausgebreitete Fettgewebs- und Gewebsnekrosen bei Pankreaskrebs. Virchows Arch. path. Anat., 297, 416-424.

Weber, F. P. (1925). A case of relapsing non-suppurative nodular panniculitis, showing phagocytosis of subcutaneous fat-cells by macrophages. Brit. J. Derm., 37, 301-311.

Zaaijer, J. H. (1935). Hautverfärbung bei akuter Pankreasnekrose. Z. Chir., 62, 250-251. 